\title{
'Conquering the Virtual Public': Jean-Paul Sartre's La tribune des temps modernes and the Radio in France
}

\author{
Alys Moody \\ University of Waikato
}

On the evening of Monday, 21 October 1947, La Tribune de Paris - a daily radio programme that provided a forum for discussion and analysis of current events - gave over its nightly news review, from 8:30 to 8:50, to 'Jean-Paul Sartre et ses collaborateurs.' This new programme, scheduled to run weekly on Monday evenings, was La tribune des temps modernes. Sartre's 'collaborateurs' were a rotating group of fellow editors of his journal, Les temps modernes, for which the radio programme was named. They included Simone de Beauvoir and Maurice Merleau-Ponty as regulars, alongside important contributions from Jean Pouillon, Jean-Bertrand Pontalis and Alain Bonafé. ${ }^{2}$ Structured as a semiscripted discussion, La tribune des temps modernes ran in the regular weekly slot for six weeks, before being abruptly cancelled in December, following a controversial run and - probably crucially - a change of government.

La tribune des temps modernes is a curious and instructive artefact of radio broadcasting history. At once famous (or notorious, depending on one's sources) and little studied, its brief history encapsulates a number of the defining characteristics of French radio in the post-war period. La tribune des temps modernes found itself caught between radio's self-image as the voice of the nation, its reality as a rather variably wielded tool of the state and its ambiguous relationship to intellectual life in France. At the same time, it proved both an expression of and a turning point for Sartre's own thinking about radio. This essay argues that La tribune des temps modernes functions in part as an indicator of the nature, status and meaning of radio in post-war France, embodying important aspects of contemporary French intellectual culture, including its uncomfortable relationships to mass media, on the one hand, and to the tumultuous politics of the day, on the other. 


\section{State power}

In 1947, French radio was still seeking to define its role in the aftermath of World War II and amidst the political tumult of the post-war years. In the years between the launch of radio in France in 1921 and the outbreak of World War II, French radio had been under the control of an ostensible state monopoly. In practice, however, the government granted a number of licenses to private operators, ensuring that the state monopoly was almost never in full force during this period. During the war, radio's importance grew substantially as a tool of both communication and propaganda. Both the Vichy government and the occupied north operated their own radio stations that combined government propaganda with entertainment. At the same time, the BBC became an important source of information for the Resistance and a crucial and highly symbolic mouthpiece for Charles de Gaulle's government-in-exile. In a very real sense, radio, as a site of both resistance and government propaganda, was a key battleground in the struggle for public support during the war years (Kuhn 1995: 83-89).

Against this backdrop, it is unsurprising that successive French governments after Liberation would place a high value on radio as the voice of the nation and, at times, also as the voice of the state. The radio's post-war nationalization was mooted by the Resistance throughout the war years, and when France was liberated in 1944, the radio was established as a state monopoly. As Hélène Eck explains, on 26 March 1945 a set of provisional conditions of operation for French radio established 'an administration with a supplementary budget, directly attached to the Ministry of Information and with a governmentappointed director' (Eck 1991: 130-131). These supposedly temporary terms, which granted the government extremely direct control over the day-to-day operation of the radio, remained in force until 1959.

In contrast to pre-war French radio, the state monopoly was rigorously enforced in post-war France on French soil. Nonetheless, there sprung up alongside this a number of radio stations - known in French as radios périphériques - which, based just outside France, recorded on and broadcast into French territory. These stations, which included Europe 1, Radio Luxembourg, Radio-MonteCarlo and Sud Radio, won an increasingly large share of the listening public during the decades following the end of World War II. They provided a form of competition for the state monopoly - although with the French government owning a controlling share in most of the radios périphériques (with the notable exception of Radio Luxembourg), this competition was largely illusory (Kuhn 1995: 92-94). From the 1970s, these stations were joined by illegal pirate 
radio stations, which broadcast from within France itself and which ultimately contributed to the fracturing of the monopoly and its eventual collapse, as part of an election promise by François Mitterand, on 9 November 1981.

The actual level of control exercised over the radio stations during the immediate post-war years seems to have been quite variable. Unlike the BBC, Radiodiffusion Française (later Radiodiffusion-Télévision française or RTF and, after 1965, ORTF) was never granted a proper charter, so its independence from government involvement was never guaranteed (Todd 1999: 193). Raymond Kuhn (1995: 91) notes that those who were seen as opposing the structures of the state - specifically, the communists, and de Gaulle and his followers - were 'largely denied access to state broadcasting' during these years, even as the high degree of government instability in post-war France made close state control of the radio relatively rare until the Algerian war. At the same time, Eck (1991: 131) observes that 'radio was an instrument of government, and it seemed normal that those who governed should come to explain their plans and their tasks, as well as their policies. If complete government control of radio was rare, politicians' understanding of the radio as a ready-made propaganda tool was not. And there were certainly notable instances of government censorship, most famously the 1947 cancellations of La Tribune des journalistes parlementaires, a discussion forum in which parliamentary journalists debated issues of the day and the cancellation, in the same year, of Sartre's La tribune des temps modernes.

La tribune des temps modernes reveals just how close the relationship between radio broadcasting and government could sometimes be in this environment. Its cancellation after only six episodes (although a total of nine were recorded) can be traced directly to state intervention in radio broadcasting, and it is this event that has won the programme its place in histories of French radio (see, e.g. Kuhn 1995; Eck 1991: 144). La tribune des temps modernes in fact courted this threat from its first programme, a vicious, entertaining and highly theatrical antiGaullist polemic, notable, amongst other outrages, for the lengthy comparison drawn by Bonafé between de Gaulle and Hitler. ${ }^{3}$ The programme predictably provoked outrage amongst de Gaulle's supporters and in the furore that followed, Simone de Beauvoir (1999: 87) wrote to her lover Nelson Algren, predicting that they would be fired in response. Christopher Todd (1999: 188n26), noting that Radio 47, the official radio programme, fails to list La tribune des temps modernes in its expected slot for 28 October, speculates that the cancellation of the programme may have been mooted by radio administration in the aftermath of this outcry. But in fact, Sartre's radio show lasted for another five episodes. When it was finally censored, it seems that the initial controversy over the 
anti-Gaullist first episode was less the issue, than the change of government that ensued. Until 19 November 1947, the French government was led by socialist Prime Minister Paul Ramadier. Following widespread strikes in November 1947 that forced his resignation and left France without a government for a week in November, Ramadier was replaced by Robert Schuman, a Christian Democrat who was significantly less sympathetic to Sartre's carefully anti-Gaullist, anticommunist leftist politics. The week Schuman assumed power, La tribune des temps modernes was cancelled. If the violently anti-Gaullist sentiments provided the germ of resistance to Sartre's programmes, it nonetheless seems that the change of government was the clear proximate cause of their eventual censorship.

There are, however, suggestions that political meddling was a feature of $L a$ tribune des temps modernes from its very inception. Writing in 1993, Michael Scriven highlights a debate over the nature and extent of the involvement of the Ramadier government in the programme. The charge is that La tribune des temps modernes, far from serving as an agent of free expression that was cut off in its prime, was in fact 'an agency of government propaganda' by the Ramadier government, a dispute that Scriven (1993: 86) resists resolving. In fact, Beauvoir's letters to Nelson Algren - first published in French in 1997 and in English in 1998, some four or five years after Scriven's study - show conclusively that not only was the radio programme commissioned and supported at the behest of Ramadier, but also that Sartre and his co-presenters knew this before the first programme went to air. ${ }^{4}$ Writing on 14 October 1947, just under a week before the programme's launch, Beauvoir explains:

The story of the radio turned a strange way. We learnt it was all contrived by the government, by Ramadier, because he wanted us to do some anti-communist and anti-Gaullist propaganda just before the elections. And we were going to be paid not by the radio (which depends upon the government but has and must have its autonomy) but by Ramadier himself. Then, we are anticommunist and anti-Gaullist, indeed, but we do not intend to support Ramadier's policy; chiefly what he did in Indochina disgusts us. So yesterday we had prepared something rather funny and striking about de Gaulle, but we decided to drop everything. Now something will happen for Ramadier though the radio people (who being mostly communist do not want our participation) had purposely said to us we were governmental agents, which he himself had tried to hide, in order to get our demission. He got very angry and told them to ask themselves for our regular participation or he would fire them. So now they are very annoyed. For us it seems a very French story and rather sad. (Beauvoir 1999: 81-82) 
Despite her claim to 'drop everything', the radio men asked them back as Beauvoir had predicted, and the members of the Tribune des temps modernes team must have relented - despite Beauvoir's (1999: 83) lament that 'Everything seems dirty in this business, all these people stink' - for the de Gaulle episode described above aired, perhaps with a week's delay, on 21 October.

In Force of Circumstance, her memoirs of the period, Beauvoir offers a slightly different - and no doubt somewhat sanitized - account of the programme's origins. Here she claims, 'One of [Sartre's] old colleagues, called Bonafé, knew Ramadier well and suggested to him that we should be entrusted with a radio programme to express our views: Sartre accepted. We did not wish to be dependent on the Présidence du Conseil; the Temps modernes hour was attached to the "literary and dramatic programs" department' (Beauvoir 1965: 137). This version - down to the 'hour' that, in the event, was only a half hour - seems to accord with Beauvoir's initial understanding of the genesis of the programme, while effacing the later revelations about government involvement. It also highlights the probably central status of Alain Bonafé. A colleague of Sartre's from the Lycée François I in Le Havre and the only regular contributor to $L a$ tribune des temps modernes who did not appear frequently in the pages of Les temps modernes during 1947, Bonafé was the connection to Ramadier, apparently the conduit for the initial proposal of the programme - and also the contributor who caused such a stir with his tactless political commentary in the first episode.

Beauvoir, describing the programme's cancellation to Algren, concludes with a sharp sense of the political motivations that shaped the existence of $L a$ tribune des temps modernes. 'The new government Schumann [sic]', she writes, 'fired us from the radio. God gave it to us (under Ramadier's features) and God took it from us, as said old wise Job. It is all right, since we were interested but did not enjoy to do this. I have better be in a quiet room and write for myself' (Beauvoir 1999: 118). For Beauvoir, the political machinations that permitted the existence of the programme are parallel to those that led to its cancellation, with the show and its presenters cast as pawns within a larger political game or - to use her own metaphor - as the playthings of competing political gods. In certain respects, this 'dirty' situation echoes Beauvoir's own earlier and far more controversial engagement with the radio during World War II. In 1943, Beauvoir was commissioned by Radio-Vichy to produce a series of radio programmes, which eventually appeared in 1944, about the origins of the music hall. These light, entertainment-oriented programmes - they appear to have been aural collages of music and street noises from various historical moments that were central to the development of music-hall, narrated by two anonymous guides - 
had no political content, but, as Ingrid Galster (1996) explains, formed part of a strategy by the Vichy government to increase the audience of their official radio station and thus of their propaganda. Small wonder, then, that she should finish by rejecting the politicized, social world of radio in favour of a retreat into the calmer world of writing alone and for oneself.

If it is clear that Ramadier played a central role in providing the Temps modernes team with a platform, it is less certain whether this exerted any sustained influence on the show's content. Beauvoir's letters emphasize that Ramadier himself believed that the combination of anti-Gaullism and anticommunism that characterized the politics of Sartre and his friends at this time was in itself enough to serve as effective propaganda for his government, without further influence from him (this is implicit in the fact that he intended their role as propagandists to be kept from them). La tribune des temps modernes delivers amply on this promise, dedicating the first show to a violent attack on de Gaulle and his supporters, the second to a sharp critique of communism and the third to a series of rebuttals of the criticism provoked by these first two programmes. Even as later episodes became more philosophical in content, they continued to call for a third way, domestically, between de Gaulle and communism, and internationally, between American capitalism and Russian communism. In this sense, they no doubt delivered on the promise that Ramadier saw in them, even if in doing so they were merely affirming their own political beliefs.

Despite the political and current affairs-oriented nature of much of $\mathrm{La}$ tribune des temps modernes, direct discussion of the Ramadier government and of Ramadier himself is strikingly absent from the programme. In this sense, it is possible that their general strategy was to simply ignore and avoid all discussion, ensuring that they could be cast as neither advocates nor critics of the prime minister. Similarly, although various contributors were keen to highlight their sympathy with colonized peoples and their support for decolonization in passing, there is no substantial discussion of decolonization or of the Ramadier government's policy in Indochina, which Beauvoir highlights as one of the key points of political difference between Sartre and Ramadier. ${ }^{5}$ This is particularly striking, in the light of the fact that the Indochina issue dominated the pages of Les temps modernes in the months before the radio programme began, producing an issue devoted to Indochina in March 1947, as well as a number of articles on the matter, including some written by regular radio contributors Jean-Bertrand Pontalis (1947) and Jean Pouillon (1947), the latter mentioning Indochina as part of a larger attack 
on French parliamentary politics. In this context, their on-air restraint with regard to both Indochina and governmental flaws more generally can easily be interpreted as a trace of Ramadier's influence.

Ramadier himself is mentioned by name only once in the show's run, in the third episode, where Sartre responds to his critics. Discussing an article that appeared in L'Humanité, the mouthpiece of the French Communist Party, in response to the previous week's episode attacking communism, Bonafé introduces the article: 'My poor Sartre, you learnt from this article that you have been sold to Ramadier'. Sartre mockingly replies:

Oh yes, I have been sold to Ramadier like I have been sold to Stalin. But how did Ramadier sell me to the United States? At the end of the day, it's the Americans who have bought me... If you are from one of the two blocs, only half the listeners will accuse me of having been sold. But since I don't belong to either one, you see, I've been bought by everyone at the same time: Ramadier, Truman and Stalin. (Sartre et al. 1989c)

As we have seen, though, the accusation that he had been bought by Ramadier is, if not strictly accurate (it is unclear from Beauvoir's letters whether Ramadier retained his financial responsibility for the programme after their discovery of his influence), certainly one that would have to be taken seriously. Given what Beauvoir and, almost certainly, Sartre and Bonafé themselves knew of how this radio programme came about, their sarcastic tone and dismissive attitude are rather disingenuous.

On the whole, though, if Ramadier got what he hoped for out of La tribune des temps modernes, it was not direct advocacy, but a simple statement of their own pre-existing beliefs, which he hoped would lead voters to favour his own leftist, anti-communist and anti-Gaullist politics. Sartre and his fellow contributors hardly needed Ramadier's influence to promote such a stance. On the other hand, it seems impossible to tell how far their avoidance of direct discussion of Ramadier, his government and those of his policies with which they disagreed should be read as an act of deference to the man who made such a public forum possible in the first place. Either way, it is clear that La tribune des temps modernes contains nothing that the contributors would not otherwise have endorsed, but also nothing that would not have ultimately pleased Ramadier. Ultimately, of course, this careful balancing act saved neither Ramadier nor the contributors to La tribune des temps modernes, all of whom had lost their jobs within six weeks of the programme first going to air. 


\section{Intellectuals Engagés}

Even if we accept that the content of La tribune des temps modernes was largely unaffected by its association with Ramadier, it remains true that the taint of political corruption must have rendered the whole affair a good deal dirtier - as Beauvoir put it - than was really desirable. The question, then, becomes why Sartre and his team went along with it at all, once Ramadier's behind-the-scenes involvement was revealed. In a letter to Algren on 26 September, Beauvoir (1999: 68-69) provides an insight into the team's initial enthusiasm: 'You know what it means? The possibility of reaching thousands of people, and trying to make them think and feel in the way we believe right to think and feel'. In Beauvoir's first flush of excitement, the possibility of radio is understood above all as the possibility of a large audience.

This has a particular relevance, and no doubt provoked a particular excitement, for the founders and editors of Les temps modernes, a journal that was established in 1945 with the express goal of fostering and promoting a 'littérature engagée.' In his essay 'Introducing Les temps modernes', first published as 'Présentation des temps modernes' in the inaugural issue of Les temps modernes in October 1945, Sartre famously declares that, 'The writer is situated in his time; every word he utters has reverberations. As does his silence' (Sartre 1988: 252). He goes on to lay out the aims of the review:

our intention is to help effect certain changes in the Society that surrounds us ... we align ourselves on the side of those who want to change simultaneously the social condition of man and the concept he has of himself. Consequently, concerning the political and social events to come, our journal will take a position in each case... If we are able to live up to what we promise, if we succeed in persuading a few readers to share our views, we will not engage in exaggerated pride; we will simply congratulate ourselves for having rediscovered a good professional conscience, and for literature's having become again - at least for us - what it should never have stopped being: a social function. (Sartre 1988: 255)

It is easy to hear echoes of Sartre's hope of persuading a few readers to share his views in Beauvoir's excitement about the possibility of an audience that 'think[s] and feel[s] in the way we believe right to think and feel'. Moreover, the radio programme seems to offer, at key points, great scope for pursuing these original aims of the journal. As a more immediate medium - some of the episodes were recorded the same day that they were broadcast - it offered a unique opportunity to take an active and direct stand on the issues of the day. At 
the same time, the discursive format allowed Sartre and the others to weave this topical commentary together with analysis of both the 'social condition of man' and 'the conception he has of himself' in a novel and engaging way. In this sense, La tribune des temps modernes must be understood as pursuing the goals of Les temps modernes by other means.

This is closely tied to one of the great preoccupations that Sartre shared with post-war French society more generally: anxiety about the status of the intellectual in post-war France. Sunil Khilnani (1993: 51-52) sees Sartre's postwar advocacy of the engaged intellectual as a response to two very serious charges levelled against French intellectuals in the aftermath of World War II: on the one hand, that they were 'social parasite[s] with nothing to contribute to the material revival of [their] country', and, on the other, that the purges of Fascist writers and intellectuals after the war left all writers 'open to charges of political naiveté and to injunctions against their further meddling in politics'. For Khilnani, Les temps modernes was Sartre's attempt to resist these criticisms, offering 'a platform in his campaign to propagate a view of writing that at once guarded its independence and endowed it with a new public importance' (52). In practice, La tribune des temps modernes may have had only mixed success in fulfilling these goals: although it offered a new audience and a new forum for the promotion of this vision of the intellectual's public importance, Ramadier's involvement must have, to some degree, shaken his independence.

Nonetheless, there are a number of reasons why the radio might have seemed like an ideal forum for an engaged intellectual in France in 1947. On a philosophical level, Hélène Eck (1991: 129) explains that radio in the immediate aftermath of the war was initially conceived of as a public forum that would ideally need to become 'a voice, capable of achieving the synthesis of democracy and culture'. Although these high-minded ideals were sullied by the government intervention described earlier, and despite the fact that an attempt to attract writers to the radio generally failed to achieve any sustained or substantive engagement from France's most famous literary names, Eck concludes that 'it did succeed in asserting itself and in making itself known as a cultural middleman with whom the elite could do business' (145). The radio was therefore uniquely positioned to act as a means of disseminating intellectual ideas to a wider audience - and that audience was indeed wide. In 1946, the French owned 5.5 million radio sets, for a population of 40 million (Kuhn 1995: 90). Nor did these sets go unused: in 1950, the average French adult spent 118 minutes per day listening to the radio (79). As a platform for reaching a wide audience, the radio was unrivalled in 1947. 
In What Is Literature?, serialized in Les temps modernes the year that La tribune des temps modernes went to air, Sartre reveals himself to be both keenly aware of the possibilities offered by the radio and somewhat wary and ambivalent about its potential. In this account, radio, like other forms of mass media, has a kind of outreach or even reconnaissance function in Sartre's great battle for the hearts and minds of the population:

We make contact with people, without ever wanting to do so, by new means, with new angles of incidence. Of course, the book is still the heavy infantry which clears and occupies the terrain. But literature has its airplanes, its V1's and V2's which go a great distance, upsetting and harassing, without bringing the actual decision. (Sartre 1949: 244)

The usefulness of radio in this account, as in Beauvoir's, lies in the enormity of its potential audience and the 'great distance' it can travel - he cites a radio adaptation of his play No Exit, which was broadcast on the BBC to an audience that he estimates at half a million. This boon comes, however, with a considerable drawback, for although the audiences are large, they are unprepared and unreceptive. In place of a discerning and critical theatre audience, Sartre worries that his radio audience simply 'wanted to hear, as usual, the Thursday drama broadcast. As soon as it was over, they forgot it, as they did the preceding ones' (245). The worry is that these large audiences transform literature into background noise and passing entertainment. It might even be asked whether the limited role accorded to them in Sartre's earlier military metaphor - where radio features as a small plane making incursions without winning the battle is not too generous in this context. Where the earlier metaphor seems to imply that mass media is responsible for dissemination but true and lasting persuasion must rely on books, an audience that is truly as disconnected and disinterested as Sartre claims might retain his name and a hint of his reputation, but little else. It risks, therefore, losing all hope of communicating ideas, surely defeating the purpose of such dissemination.

If the analysis stopped there, it would be hard to see why Sartre should have bothered with radio at all, except perhaps, as Todd (1999: 196) claims, as 'merely another publicity stunt. But Beauvoir's letters offer a quite different account of the Temps modernes group's attitude towards this programme, describing it as one of 'these opportunities of doing something real and concrete' (Beauvoir 1999: 72), observing that the radio's potential to reach such a large audience 'must be managed with much care' (69), and often complaining about the long hours and obsessive effort devoted to the programme. This points to a sense of 
commitment and seriousness in their approach to La tribune des temps modernes, which seems to carry them far from the flippancy of Todd's 'publicity stunt'.

As Sartre's discussion of radio and mass media in What Is Literature? continues, he begins to gesture towards a sounder foundation for radio's appeal. For Sartre, the problem to which radio might be a solution is, crucially, one of audience; specifically, the problem is that contemporary French writers have 'readers but no public' (Sartre 1949: 246). Although bourgeois, they are alienated from their origins by their commitment to overturning the oppression of which the bourgeoisie is instrument and beneficiary. On the other hand, the Communist Party has dominated the working class, preventing them from finding a public there. As such, writers struggle to speak to a class, to form a community through their writings: they lack, in short, a public. To counteract this, Sartre argues that committed writers must seek out their 'virtual readers, that is, the social categories that do not read us, but which might' in an attempt to 'incorporate some of our potential readers into our actual public' (267-268). For this, Sartre proposes enlisting the help of the mass media, which he describes as 'the real resources at our disposal for conquering the virtual public' (268).

But how to deploy these resources without falling into the trap described earlier, whereby the passive and disinterested audience encounters then forgets the programme, without ever according its ideas the full and close attention they require? Sartre's solution lies in a refusal of adaptation in favour of specificity to the medium: 'It is by no means a matter of letting our works be adapted for the screen or the broadcasts of the French Radio. We must write directly for the movies and the airwaves' (269). The primary reason that he gives for this demand is the need to avoid and circumvent the industrial processes that underpin the mass media and which seek to make works mediocre in order to appeal to the public more successfully. In place of adaptations of works written for other media, Sartre insists that 'there is a literary art of radio, film, editorial and reporting. There is no need to popularize' (268). The potential for taking advantage of the radio, then, is understood as relying on an ability to creatively exploit the specificities of the medium.

For Sartre, the specificity of radio, in particular, seems to lie in its intimacy. Describing the possibilities that it could offer an astute writer, he explains:

The radio surprises people at the table or in bed, at the moment when they are most defenceless, in the almost organic abandon of solitude. At the present time, it makes use of its opportunity to fool them, but it is also the moment when one might better appeal to their good faith; they have not yet put on or have laid 
aside the personality with which they face the world. Weve got one foot inside the door. We must learn to speak in images, to transpose the ideas of our books into these new languages. (Sartre 1949: 268)

Unlike books, which he describes as 'inert' in their need to be chosen by the listener, the radio is capable of infiltrating people's lives in their most exposed and vulnerable moments. The combination of surprise and intimacy makes the radio a double-edged sword: capable of becoming highly exploitative, but also of appealing to an audience in a more direct manner, of bypassing the defences erected and maintained by their public faces, as well as by their choice of reading material. To the vast scale of the listening public, Sartre adds radio's unusual intimacy, a combination that makes it uniquely suited to the reconnaissance function he attributes to mass media. At the same time, though, radio, like all mass media, retains its secondary status in relation to books. Ideas are never formulated directly in the 'languages' of radio and other mass media; rather, books remain the privileged site of real intellectual work, while radio and related media function exclusively as translations.

\section{Writing for the radio}

La tribune des temps modernes, which went to air the same year that What Is Literature? was published, remains Sartre's only serious engagement with the radio and his only real attempt to realize his hopes for the medium. It therefore offers a fascinating insight into what he understood 'writing directly for the ... airwaves' to look like. Indeed, La tribune des temps modernes is nothing if not written - or conceived - directly for radio. It exploits its medium in a range of ways, from its discursive format and its emphasis on audience involvement, to its integration of current events with philosophical discussion, and its use of theatrical and comic elements. It was clearly conceived as a dynamic and engaged dialogue with an audience with whom the contributors have been granted an unusual intimacy.

A full understanding of how precisely Sartre 'writes for the radio' requires a consideration of the format and form of La tribune des temps modernes. The evidence for this comes primarily from a series of cassette recordings, released by Radio France in 1989, of nine episodes of this programme. These recordings exclude the initial 6 October episode that Todd highlights, but include the remaining six episodes, first broadcast between 20 October and 24 November 1947 , alongside an additional three programmes that were recorded prior to the 
show's cancellation and projected for broadcast on 1, 8 and 15 December. The episodes available through this series are, in order of first broadcast:

20 October Gaullism and the RPF

27 October Communism and anti-communism

3 November Listeners' letters and definitions of existentialism

10 November Liberalism and socialism

17 November The crisis of socialism

24 November Union movements and social conflicts

1 December The true meaning of the workers' demands

8 December Two appeals to international opinion

15 December David Rousset on his return from Germany

These recordings have been taken from a rebroadcast (or, in the case of the latter three, first broadcast) of the entire series on France Culture in August 1989. The cassette versions therefore include the addition of a small amount of contextual information at the beginning of the broadcasts, short interviews with relevant figures at the end and a helpful voice-over explaining who is speaking during the programme itself.

Each episode features at least four contributors engaged in discussions that, while often framed by Sartre and often consensual in their conclusion, were clearly conceived to give the impression of genuine but civil debate. The participants frequently interrupt each other, correct each other and pose questions either to the group or directly to one or the other of the contributors. Although individual speakers are given time to develop their thoughts and arguments in some detail, and although Sartre and - when present - Merleau-Ponty are given more airtime and more central roles than the others, the overall effect is of a congenial, if passionate and in-depth, discussion amongst friends. In this, the programme adopts the tribune format popularized by La Tribune de Paris and La Tribune des journalistes parlementaires. Sartre had experimented with conversational formats in print before - there is, for example, a lengthy post-lecture discussion reproduced at the conclusion of Lexistentialisme est un humanisme, which was published the year before (see Sartre 1996: 79-109) - but the conversational mode of La tribune des temps modernes is distinguished by the fact that it seems to produce a genuine and relatively non-hierarchical discussion. Given that they were originally aired at 8:30 in the evening, La tribune des temps modernes was likely to have 'surprise[d] people at the table', and the programme's format, like 
that of other contemporaneous discussion-based radio shows, can be read as an attempt to stage and participate in the evening dinner table conversation.

The listening public were envisaged as partaking in this conversation, with Sartre in particular seeking to work audience responses into the fabric of the radio programme. In the wake of the polemical attacks on Gaullism and communism in the programme's first two episodes, and of the vehement public reaction they provoked in the press and media of the day, the third episode of La tribune des temps modernes is given over to Sartre's responses to his outraged listeners. As several of his collaborators read out letters or summarize news articles about the programme, Sartre offers his provocative and satirical responses. But if the format is designed to incorporate a certain responsiveness to listeners' concerns, its rhetoric treats them more as objects for study than as interlocutors in a genuine dialogue. Sartre opens the episode by announcing:

I have received letters of congratulations, naturally, and equally naturally, letters of attack and insult. It is these latter that I want to speak to you about, because I find that they express a curious and worrying state of mind. (Sartre et al. 1989c)

By reading these responses as symptomatic of a broader French malaise, Sartre avoids engaging them directly in any kind of debate. Selecting extreme accusations, he ridicules their assertions before holding them up as examples of his analysis of post-war French society. Thus, their logical flaws are read as indicative of 'the idea that the value of thought has been undermined, the supremacy of the lie over the truth, of tactic over logic, of interests over the thought of the interested'. Similarly, claims that he is operating as an agent for either the Russians, the Americans or Ramadier are seen as emblematic of the paranoid French mindset of the day: 'We think we are still under the occupation ... we think that there is a foreign dictator in France, threatening and murderous, who reveals himself everywhere in everyday life, as well as in major events ... At bottom, we think the situation of ' 47 with the words and the means of 1943'. If this stands as an interesting analysis of post-war French society, it also has the effect of silencing his critics by denying the autonomy and value of their claims. But in an important sense, La tribune des temps modernes is not speaking to these critics. As What Is Literature? reveals, Sartre conceived of radio as a way of reaching a 'virtual public' of those predisposed towards his ideas, but who do not yet constitute an actual public. It seems hardly likely that he would have included listeners who referred to himself as 'un dégueulasse' (a swine) and Simone de Beauvoir as 'une bonne femme boche' (a good kraut woman) amongst such potential supporters. 
Nonetheless, La tribune des temps modernes does show signs of addressing itself directly to the 'virtual public'. The eighth episode of the series, one of those which was recorded but never broadcast, is particularly illustrative in this regard. This episode, often dismissed by commentators as amongst the most dull, consists primarily of the reading of two manifestos, both calling for the emergence of a strong, unified and socialist Europe as a bulwark against the emergent Cold War tensions between the USA and the USSR. Introduced as explicitly written texts, which need to be 'read' on air and which Sartre claims at the beginning of the episode have recently appeared in unnamed newspapers, these manifestos stray furthest from Sartre's call to write directly for radio, rather than simply adapting texts from the print media. In practice, this episode strives to make these manifestos an occasion for debate, with Pontalis and Bonafé assuming the roles of a sceptical audience, whose broad agreement with Sartre on many issues is pitted against a professed reluctance to sign such statements blindly. After having forced Sartre to defend the manifestos at length, the programme concludes with an appeal to their listening audience: 'I believe that it would be good to ask the listeners to send their agreement, if they agree, or their disagreement ... to say whether ... they too want to sign this manifesto and to say it by sending it to the radio' (Sartre et al. 1989h). If audience response remains significant here, this episode takes a dramatically different approach to the mockery and analysis of the third. Here, Pontalis and Bonafé emerge as the avatars of Sartre's 'virtual public', interrogating Sartre's position before standing aside at the end of the programme to allow the virtual public to sign on as an actual public.

The attention to radio broadcasting as a specific genre of speech takes its frames of reference not only from Sartre's elaboration of the intimacy of radio as a form, but also from the nature of radio discussion as practiced on French radio in 1947. The title of La tribune des temps modernes echoes both La Tribune de Paris, of which it was a part, and La Tribune des journalistes parlementaires, the journalist's discussion forum, which was banned twice in 1947. The tribune was in fact something of a radio genre in its own right, in which contributors discussed the events of the day in a round-table format. In this sense, the conversational format of La tribune des temps modernes can be understood as reasonably conventional, as can its highly topical subject matter. In fact, current affairs and contemporary politics remain a constant touchstone for Sartre's radio programme. The first episode, broadcast the day after de Gaulle's newly formed party, the Rassemblement du Peuple Français (RPF) enjoyed sweeping success at the municipal elections, is a vicious attack on de Gaulle. The second episode, an attack on communism, is also highly topical, coming as it does 
during the early days of the Cold War and during the year in which the PCF was exiled from government and figures such as Léon Blum were arguing for a third way between the RPF and the PCF. Merleau-Ponty's attack on the inequality and state oppression in the USSR seems particularly prescient for a leftist in 1947. After a foray into more philosophical discussion of political movements such as liberalism and socialism in episodes 4 and 5, La tribune des temps modernes returns to the issues of the day with an extended examination of the extensive strikes that shook France in November 1947. The sixth episode features an interview with a trade union leader opposed to the strikes, whereas the unbroadcast seventh episode promises an interrogation of 'the real meaning of the worker's demands'. The eighth consists of the manifestos discussed above. The recorded programmes conclude with an interview with David Rousset, a former concentration camp inmate who had risen to prominence with the publication of a fictional and a non-fictional account of the camps, and who would, the following year, be the co-founder of Sartre's own short-lived political party. In the ninth episode, Rousset discusses a recent trip to Germany, giving a detailed report on the political and social circumstances of contemporary Germany.

In keeping with the cultural focus of La Tribune de Paris, La tribune des temps modernes moves fluidly from these discussions of current events and contemporary politics to larger philosophical questions. The third episode is again exemplary here, using the diagnosis of listeners' letters as a means of moving from the news-driven analyses of Gaullism and communism, to a more explicit exposition of existentialism as a philosophical movement with a political interest. Sartre, disdaining popular misappropriations of existentialism, insists:

what I prefer is to try to demonstrate precise points by which this philosophy forces a choice on us, a political choice, and forces us to struggle against the present situation. The existentialist's big idea is precisely to struggle against sentiment and impotence. We think that man is never impotent, except when he believes he is. (Sartre et al. 1989c)

This cornerstone of existentialist thought therefore becomes a diagnostic tool for contemporary French society. Similar movements characterize the following two episodes in particular. The fourth, for example, evaluates liberalism and socialism through an analysis of different kinds of and claims to freedom, dismissing liberalism's 'abstract rights' in favour of what they see as socialism's greater concreteness (Sartre et al. 1989d). The fifth episode follows directly on from this, reading the philosophical discussion of the fourth against contemporary 
events, as Merleau-Ponty advances a claim for the crisis of socialism, noting carefully, 'when I spoke the other day about a crisis of socialism, I didn't mean a crisis of a theory or a doctrine, but above all of the crisis of a movement' (Sartre et al. 1989e). This back-and-forth is typical of the discussion on La tribune des temps modernes, where political analysis is always informed by the contributors' underlying philosophical stance and philosophical claims are often tested against contemporary events. The result is a programme that assiduously tries to speak in the language of radio and abide by its conventions while avoiding popularization that might trivialize or simplify the philosophical component.

\section{Postscript}

La tribune des temps modernes therefore seems to have been a serious endeavour for Sartre, an attempt to realize his hopes of reaching a wider public. Nonetheless, it remains exceptional in his career as his only attempt to use the radio in this way and as one of his few appearances on the radio at all. This is not true of all members of La tribune des temps modernes group - Merleau-Ponty, for instance, went on to deliver a series of lectures on perception on Radio France the following year (published as Merleau-Ponty 2004). So why did Sartre abandon the radio in this way? Todd (1999: 191) claims that, in the wake of the controversy surrounding La tribune des temps modernes, 'there seems to have been a positive effort to prevent [Sartre] from using the radio as a political forum again'. Be that as it may, Sartre himself seems to have been resistant to further attempts to use radio broadcast as a political or philosophical medium after the cancellation of La tribune des temps modernes. At the very least, even if he were unofficially banned from Radio France, he could always have pursued broadcasts on the radios périphérique, as he did briefly during the 1968 manifestations, when he voiced his support for the protestors on RTL. That he chose not to pursue this any further implies a wider disillusionment with radio as a medium for communicating his ideas.

This is confirmed by Sartre's other major theoretical discussion of the radio, in his 1960 work Critique of Dialectical Reason. In this, his most political work of philosophy, Sartre condemns radio as an example of a 'collective', his term for a collection of individuals who, in their isolation, fail to achieve the integration necessary to become a group capable of achieving political change. Sartre's critique of radio is interesting not only for his brusque dismissal of 
radio's political potential, but also because its terms of analysis seem to imply the inevitable failure of his attempts to write for the radio. Sartre offers radio as an example of what he calls an 'indirect gathering', in which the listeners, joined together in the event of the radio broadcast, are isolated from others and experience their fellow listeners only in their absence from them. He proceeds to offer an analysis of radio from two perspectives: the relationship of the listener to the radio broadcaster and that of the listener to other listeners.

In the case of the former, he argues that 'the relation between the broadcaster and myself is not a human one: in effect, I am passive in relation to what is being said' (Sartre 2004: 271). He goes on to characterize this passivity in terms of the lack of reciprocity between listener and broadcaster:

The broadcaster's voice, in contrast [to that of a public speaker], in its reality as a human voice, is, in principle, mystifying: it is based on the reciprocity of discourse, and therefore on a human relation, but it is really a reifying relation in which the voice is given as praxis and constitutes the listener as object of praxis; in short, it is a univocal relation of interiority, similar to that of the organism acting on a material environment, but one in which I, as an inert object, am subjected as inorganic matter to the human work of the voice. (Sartre 2004: 272)

It is precisely this objectifying lack of reciprocity that Sartre's engagement with his audience attempts to guard against. In the Critique of Dialectical Reason, however, this possibility seems to have been removed and the inhuman relation between broadcaster and listener rendered structural. He dismisses both the possibility of individual listeners 'speaking back' to the radio and that of listeners simply turning the radio off, on the grounds that in both cases the response is ineffective unless it is expressed en masse. And here, the problem of absence raises its head. He writes that, 'as soon as I imagine some practical action against what the broadcaster says, I can conceive of it only as serial: I would have to take the listeners one by one... Obviously, this seriality is a measure of my impotence' (Sartre 2004: 273). Because we have no direct relation to other listeners, the possibility of mobilizing them as a group is seriously attenuated. Nonetheless, he emphasizes, it is on their behalf that we worry: our fury at a radio broadcast with which we disagree arises from our concern that other listeners may be persuaded - and that, in our absence from them, we will have no recourse, no platform from which to refute these false claims.

By 1960, then, radio had become an embodiment of political impotence, of organizations of individuals rendered powerless by the structure in which they are caught. This is a far cry from the guarded optimism of the analysis of radio in What Is Literature? and it implies a significant shift in perspective. Where What 
Is Literature? speaks as a 'we' that includes writers-as-radio-broadcasters, about a 'they' of the listening public, in Critique of Dialectical Reason, Sartre assumes the position of the alienated listener, describing the experience in the first person singular. As such, the focus of the radio's political potential is no longer on the ability of the broadcaster to mobilize popular opinion - a tactic that seems to have been recast as both ethically and politically questionable - but rather on the ability of the radio broadcast to function as an occasion for concerted communal action. Where there was some hope for the former for Sartre in 1947, the structural conditions of radio seem to have ensured the impossibility of the latter by 1960. If La tribune des temps modernes seemed to Sartre to have been a doomed experiment, it seems clear that by 1960 he was attributing this failure not simply to the political interference that surrounded it, but to the very nature of radio itself.

\section{Notes}

1 On La Tribune de Paris, see Nord (2010: 353). On the timing and details of Sartre's radio programme, see Todd (1999: 185).

2 Bonafé is sometimes confused with Lucien Bonnafé, a well-known French psychiatrist who was also active in Paris in this period. Nonetheless, he is clearly identified in all radio broadcasts as 'A. Bonafe' and a Bonafé appears in several of Simone de Beauvoir's autobiographical works, identified not as a psychiatrist but as a high-school literature teacher (see, e.g. Beauvoir 1990a; b: 103).

3 Todd (1999: 186) disagrees that this was in fact the first episode and cites an earlier one, on 6 October. He cites contemporary French radio guides to support this claim. However, as I have been able to find no further reference to this episode, either in histories of the radio and Sartre's engagement with it or in Simone de Beauvoir's letters and memoirs, and as this initial programme is not included amongst those rebroadcast and subsequently released on cassette by Radio France in 1989, I have used the more widely verified starting date.

4 If Todd is correct about the 20 October episode in fact being the second of the Tribune des temps modernes series - a claim that is neither confirmed nor denied by Beauvoir's letters - this might provide an alternate explanation for why the programme failed to air as expected on 13 October.

5 In the second episode, 'Communisme et anticommunisme', Merleau-Ponty attacks the USSR for having a 'colonial policy that threatens the liberation of colonised peoples,' while in the fifth, on 'La crise du socialisme', Pontalis cites 'the war that the colonised countries wage for their independence' as an instance of the contemporary relevance of class warfare. 


\section{Works cited}

Beauvoir, S. de (1965). Force of Circumstance, trans. R. Howard. London: Deutsch. (1990a). Journal de guerre. Paris: Gallimard. (1990b). Lettres à Sartre. Paris: Gallimard. (1999). Beloved Chicago Man: Letters to Nelson Algren 1947-1968. London: Phoenix.

Eck, H. (1991). 'Radio, Culture and Democracy in France in the Immediate Postwar Period, 1944-50', in France and the Mass Media, Ed. B. Rigby and N. Hewitt. Houndmills: Macmillan, pp. 129-146.

Galster, I. (1996). 'Simone de Beauvoir et Radio-Vichy: A propos de quelques scenarios retrouvés', Romanische Forschungen, 108.1-2, pp. 112-132.

Khilnani, S. (1993). Arguing Revolution: The Intellectual Left in Postwar France. New Haven: Yale University Press.

Kuhn, R. (1995). Media in France. London: Routledge.

Merleau-Ponty, M. (2004). The World of Perception, trans. O. Davis. London: Routledge. Nord, P. G. (2010). France's New Deal: From the Thirties to the Postwar Era. Princeton: Princeton University Press.

Pontalis, J.-B. (1947). 'Un soldat français en Indochine', Les temps modernes, 17, pp. 895-905.

Pouillon, J. (1947). 'Mythe contre mythe', Les temps modernes, 20, pp. 1345-1360.

Sartre, J.-P. (1949). What Is Literature?, trans. B. Frechtman. New York: Philosophical Library.

- (1988). 'Introducing Les temps modernes', in 'What Is Literature?' and Other

Essays, trans. J. Mehlman. Cambridge: Harvard University Press, pp. 249-267.

- (1996). Lexistentialisme est un humanisme. Paris: Gallimard.

- (2004). Critique of Dialectical Reason, volume 1, Ed. J. Rée, trans. A. Sheridan-

Smith. London: Verso.

— S. de Beauvoir, M. Merleau-Ponty, J.-B. Pontalis and A. Bonafé (1989a).

'Le Gaullisme et le R.P.F', in La tribune des temps modernes. Paris: Radio France. First broadcast 20 October 1947.

— S. de Beauvoir, M. Merleau-Ponty, A. Bonafé and J.-B. Pontalis (1989b).

'Communisme et anticommunisme', in La tribune des temps modernes. Paris: Radio

France. First broadcast 27 October 1947.

— S. de Beauvoir, J. Pouillon, A. Bonafé and J.-B. Pontalis (1989c). 'Lettres

d'auditeurs et définitions de l'existentialisme', in La tribune des temps modernes. Paris:

Radio France. First broadcast 3 November 1947.

_ S. de Beauvoir, M. Merleau-Ponty, A. Bonafé, J.-B. Pontalis and J. Pouillon (1989d). 'Libéralisme et socialisme', in Tribune des temps modernes. Paris: Radio France. First broadcast 10 November 1947. 
M. Merleau-Ponty, A. Bonafé and J.-B. Pontalis (1989e). 'Crise du socialisme', in La tribune des temps modernes. Paris: Radio France. First broadcast 17 November 1947.

, A. Bonafé, J.-B. Pontalis and J. Pouillon (1989f). 'Mouvements syndicaux et conflits sociaux', in La tribune des temps modernes. Paris: Radio France. First broadcast 24 November 1947.

— S. de Beauvoir, A. Bonafé, J.-B. Pontalis and J. Pouillon (1989g). 'Vrai sens des revendications ouvrières', in La tribune des temps modernes. Paris: Radio France.

S. de Beauvoir, A. Bonafé and J.-B. Pontalis (1989h). 'Deux appels à l'opinion internationale', in La tribune des temps modernes. Paris: Radio France.

A. Bonafé, J.-B. Pontalis and J. Pouillon (1989i). 'David Rousset de retour d'Allemagne', in La tribune des temps modernes. Paris: Radio France.

Scriven, M. (1993). Sartre and the Media, New York: St Martin's Press.

Todd, C. (1999). 'Sartre Flirts with the Radio', in Making Connections: Essays in French Culture and Society in Honour of Philip Thody Ed. J. Dolamore. Bern: Peter Lang, pp. 183-196. 